\title{
Effects of water stress applied at different phenological phases on yield components of dwarf bean (Phaseolus vulgaris L.)
}

\author{
Brahim Mouhouche ${ }^{\mathrm{a}}$, Françoise Ruget ${ }^{\mathrm{b} *}$, Richard Delécolle $^{\mathrm{b}}$ \\ a Institut national agronomique (INA), 16200 El-Harrach Alger, Algeria \\ ${ }^{\mathrm{b}}$ Inra, unité de bioclimatologie, Domaine Saint Paul, F - 84914 Avignon cedex 9, France
}

(Received 17 January 1997; accepted 14 April 1998)

\begin{abstract}
Drought treatments were applied to seven sets of dwarf bean plants in pots. Each was subjected to water stress during one of the seven phenological phases, ranging from bud stage to grain filling. Treatments consisted of withholding irrigation until $80 \%$ of the available water capacity was used. Evidence of differential effects of water stress according to the phase of application was obtained by tagging all the floral organs (buds or pods) present during the phase. Fallen tags indicated how many organs had aborted before physiological maturity. Periods of flowering (p1: bud, p2: flower opening, p3: fruiting set) were more sensitive than pod elongation (p4 and p5) and grain filling (p6 and p7) phases. Bud abortion rate was $50 \%$ in non-stressed plants and $70 \%$ in stressed ones. The final pod number was $53 \%$ lower in plants stressed during the pl period (the most sensitive period) than in controls. Pod number was generally much more sensitive to drought than the seed number per pod, which was only $13 \%$ lower than in controls for plants stressed during the pl period. (@ Inra/Elsevier, Paris.)
\end{abstract}

Phaseolus vulgaris / yield component / water stress / phenological phase

Résumé - Effet d'un stress hydrique appliqué à différentes phases phénologiques sur les composantes du rendement du haricot nain (Phaseolus vulgaris L.). Nos essais ont pour but d'étudier l'effet d'un stress hydrique de même intensité appliqué à différentes phases phénologiques de la période de reproduction, sur les composantes du rendement exprimées en nombre, du haricot nain (Phaseolus vulgaris L, variété Coco de Prague). Afin d'éviter le phénomène de chevauchement des différents organes fructifères, la période de reproduction est divisée en sept phases phénologiques, de la phase bouton floral à la phase de fin remplissage des gousses. Chaque phase subit une seule fois le stress durant tout le cycle végétatif. Ce stress correspond à un déficit de consommation en eau égal à un taux de tarissement en eau du sol en fin de stress de $80 \%$ de la réserve utile (RU). Le marquage systématique de la période à laquelle les organes

Communicated by John McAneney (Kerikeri Bay of Islands, New Zealand)

* Correspondence and reprints

E-mail: ruget@avignon.inra.fr 
fructifères ont été stressés permet de montrer une plus grande sensibilité de la période dite de floraison qui englobe les phases bouton, fleur épanouie et nouaison (p1, p2 et p3), par rapport aux phases post-florales, correspondant aux phases d'élongation ( $\mathrm{p} 4$ à p5) et de remplissage des gousses (p6 à p7), ces dernières étant les moins sensibles. Les résultats obtenus montrent l'importance de la probabilité d'avortement d'un bouton floral qui est de $50 \%$ pour un bouton non stressées et $70 \%$ pour un bouton stressé. Le nombre de gousses par plante (NGo/Pt) est la composante la plus sensible au stress hydrique, avec une différence de $53 \%$ par rapport au traitement témoin conduit en évapotranspiration maximale (ETM), non stressé. Le nombre de graines par gousse ( $\mathrm{NGr} / \mathrm{Go}$ ) est moins sensible au stress hydrique que le nombre de gousses par plante, avec une réduction maximale de $13 \%$ par rapport au témoin. (@ Inra/Elsevier, Paris.)

\section{Phaseolus vulgaris / composante du rendement / stress hydrique / phase phénologique}

\section{INTRODUCTION}

Under natural conditions, owing to its temperature requirements, the bean is often cultivated at a time when water stress is probable. It is well known that water stress reduces dry matter and seed production, to a degree which depends on the intensity, the length and the frequency of stress. Among grain legumes, the bean (Phaseolus vulgaris L.) is particularly susceptible and its poor adaptation to climatic stresses [20] can be partly explained by its long reproductive period, which can last between 25 and 35 days representing 35 to $45 \%$ of the total cycle length $[19,32]$. The effects of stress have a major economic impact since the bean is a food crop and a useful source of proteins. This motivated our study which aimed at quantifying the effects of controlled water on yield components (expressed in number of organs in this paper, in weight in the next) according to the period of application.

Stress applied during the vegetative development phase often has no direct effect on bean yield [19], although some authors consider that water supply during this phase is harmful [14] because it does not favour deep rooting - one of the main resistance features to drought $[23,30]$. Conversely, during the reproductive period, water stress has a major effect on the development of the different yield components [1]. When applied during the flowering period (p1-p3), water stress mainly acts on the pod number per plant $(\mathrm{NPo} / \mathrm{Pt})$ and, to a lesser extent, on the seed number per plant (NS/Pt) or per $\mathrm{m}^{2}[8,23]$ in beans; $[3,28,29]$ in soya).
Water stress also shortens the flower initiation period (bean: [23]; pea: [7, 17].

The sensitivity of yield components to water stress varies. In the mung bean (Vigna radiata Wilczeck), Kuhad et al. [13] obtained a decrease in the pod number per plant $(\mathrm{NPo} / \mathrm{Pt})$ five to seven times higher than the change in the mean weight of the seed. In the bean, De Malgalhaes et al. [6] obtained a $31 \%$ decrease of NPo/Pt and only $18 \%$ for NS/Pt. Romic et al. [22] applied supplementary irrigation to beans during the reproductive period and showed pod number to increase from 36 to $105 \%$ depending on the year. The latter figure implies that production at low water deficits was higher when water was unrestricted. This variability in results originates from the diversity of the stress intensities applied, a lack of standardization in experiments, and the inaccuracy of the stages at which they are applied. This latter factor is the main interest of this paper.

The length of the stages and the time-lag between flowers on a given plant lead to the presence of several stages simultaneously on the same plant, from the bud stage to the filling stage. This overlapping has already been mentioned for grain legumes ([31] for the chick pea; [7, 11, 18] for the pea; $[14,16]$ for the bean). This overlapping was more pronounced in climbing species, which have a longer reproductive period [9]. In order to study the overlapping, we monitored the fruiting organs with individual tags, in order to distinguish between the vegetative and the flowering stages. The results were obtained when physiological maturity was reached and represented the mean effect of the same stress applied to fruiting organs 
at different phenological stages. The experiment was carried out in a greenhouse and in containers in order to control stress, in particular to avoid untimely rainfall.

\section{MATERIALS AND METHODS}

\subsection{Crop management}

The experiments were carried out at the experimental station of the Institut national agronomique (INA) at Algiers. Beans were sown in September 1992, March 1993 and March 1994 in a greenhouse made of frosted glass and equipped with a cooling and aeration system. Mean temperatures and insolation duration during the experiments are given in table $I$. The glass house was ventilated to avoid overheating, except when there was a risk of rain. Growing the beans in containers made it possible to control the drying up rate of the soil during the stress period, by weighing pots every 2 days.

The experimental design was completely randomized with two water regimes, i.e. stressed and non-stressed and seven phenological phases. Each treatment was replicated four times on batches of six plants. The seven phenological phases are described in table II. Bud, flower opening and fruit set phases are identified as p1, p2 and p3, respectively, and $\mathrm{p} 4, \mathrm{p} 5, \mathrm{p} 6$ and $\mathrm{p} 7$ representing pod elongation and filling at 25,50,75 and $100 \%$ of the normal length (L) of the pod at physiological matu-

Table I. Climatic data during experiments.

\begin{tabular}{|c|c|c|c|c|c|c|c|c|c|c|c|c|}
\hline \multirow{2}{*}{$\begin{array}{l}\text { Experimental year } \\
\text { Date of crop }\end{array}$} & \multicolumn{4}{|c|}{1992} & \multicolumn{4}{|c|}{1993} & \multicolumn{4}{|c|}{1994} \\
\hline & Sep & Oct & Nov & Dec & Mar & Apr & May & Jun & Mar & Apr & May & Jun \\
\hline Temperature $\left(\mathrm{C}^{\circ}\right)$ & 27.2 & 22.7 & 19.5 & 18.5 & 17.9 & 20.4 & 23.6 & 27.2 & 19.6 & 17.8 & 23.7 & 25.1 \\
\hline $\begin{array}{l}\text { Monthly insolation } \\
\text { duration }(\mathrm{h})^{*}\end{array}$ & 207.0 & 149 & 148 & 92 & 176 & 172 & 227 & 233 & 180 & 195 & 243 & 266 \\
\hline
\end{tabular}

Table II. Phenologicals phases of tagging reproductive organs.

\begin{tabular}{lllll}
\hline Symbols & $\begin{array}{l}\text { Phenological } \\
\text { phases }\end{array}$ & $\begin{array}{l}\text { Length } \\
(\mathrm{mm})\end{array}$ & $\begin{array}{l}\text { Days after } \\
\text { seeding }\end{array}$ & Reproductive organ \\
\hline pl & bud & 31 & 38 \\
p2 & flower opening & $<10$ & 44 \\
p3 & fruit set & 35 & 49 & 54 \\
p4 & beginning of & & 59 \\
p5 & elongation & 70 & 64 & \\
p6 & end of elongation & 110 & 140 &
\end{tabular}

$\mathrm{p} 1, \mathrm{p} 2, \mathrm{p} 3$ : correspond respectively to floral phases (bud, opened flower, fruit setting).

p4, p5, p6, p7: correspond respectively to phases: $25,50,75$ and $100 \%$ of the final length of the pod (physiological maturity) 
rity. After pre-germination in fertile pots, plants were cultivated in individual containers $(30 \mathrm{~cm}$ in diameter and $30 \mathrm{~cm}$ high). The cultivar chosen, Coco de Prague, was an indeterminate semi-climbing type, so each plant was staked.

\subsection{Implementing water stress and calculating irrigation requirements}

Stress treaments, which consisted of withholding irrigation, were started when the largest number of flowers or pods were in the appropriate phenological phase. At the beginning of the stress period, the water content of each pot was at field capacity. Stress was relieved when the $80 \%$ of the soil available water (AW) had been exhausted.

Water requirements of the crop were determined using the mean maximal evapotranspiration (MET) of ten lysimetric containers, or evapotranspirometers carrying the same crop. The difference between the amount of water supplied and that drained was calculated every 2 days in each container. The daily mean maximal evapotranspiration was equal to:

$$
\mathrm{MET}=1 / 10(I-D \pm V s)
$$

where $I$ is the mean irrigation of ten containers $(\mathrm{mL}), D$ the mean drainage of ten containers $(\mathrm{mL})$ and $V s$ the initial mean variation of the water content in ten containers. $V s$ variation is negligible in comparison to the amounts of water supplied over 10 days. Lysimetric containers were cultivated under the same conditions as the experimental containers.

Containers were weighed to measure the drying of soil. Field capacity (FC) was first determined on the same soil in the laboratory with 'Richard's method', which made it possible to determine the characteristic soil water retention or $\mathrm{pF}$ curve and translate soil water content to $\mathrm{pF}$ values.

Irrigation was re-established when the container weight had lost $80 \%$ of the available soil water. Thereafter, the soil of containers was restored to field capacity and managed under an optimum water regime until the end of the cycle.

\subsection{Tagging fruiting organs}

Tagging fruiting organs and collecting fallen tags daily made it possible to interpret the effect of stress on abortion every $3-5$ days in summer (5-8 days in winter). The ratio of the total number of fallen organs, from tagging to harvest for a given treatment, to the number of tagged organs at the end of the stress period gives the probability of an organ aborting during a given stage before the end of filling. The relative abortion rate is the ratio of the abortion rate of a stressed plant to that of a control plant from the tagging date to physiological maturity.

The phase of stress application used in data analysis is the fruiting organ phase rather than the fruiting plant phase.

Statistical analyses using analysis of variance technique were undertaken with irrigation strategy and the period of stress application as treatments. We grouped together trials with two classification criteria for the abortion rate and with one classification criterion for the other yield components. The least significant difference (LSD) was determined for the yield components having a significant difference at the $5 \%$ threshold.

\section{RESULTS}

\subsection{Intensity and stability of the stress applied}

The soil water content at the end of the stress period which was measured in a few containers and the soil water potential inferred from the $\mathrm{pF}$ curve $(\psi, \theta)$ : the potential in all cases was between -0.85 and $-0.90 \mathrm{MPa}$.

The duration of the stress varied between crops (9-14 days) (table III). It was slightly longer in the autumn crop (1992) due to the low evapotranspiration rate in this season. In practice, real stress started when the drying up rate reached $50 \%$ of the soil available water. The duration of real stress thus 


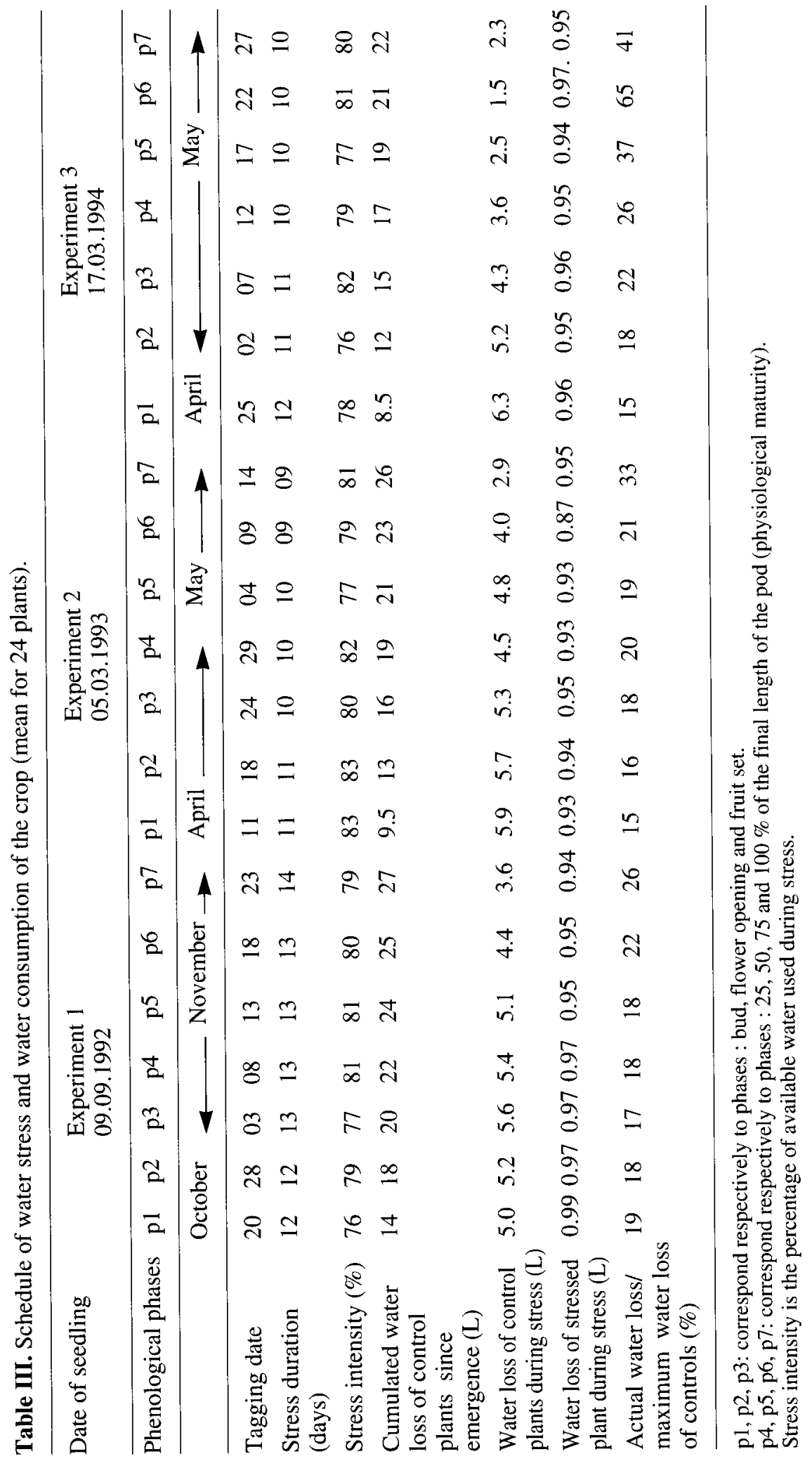


varied from 5 to 7 days with increasing severity towards the end of the stress application period (figure 1). The stress was also estimated in terms of the ratio of AET (actual water loss)/MET (maximum water loss of controls) (table III).

\subsection{Overlapping: simultaneous presence of several stages}

The results obtained in our three experiments showed that overlapping was an extensive phenomenon. For example, 12 days after the beginning of
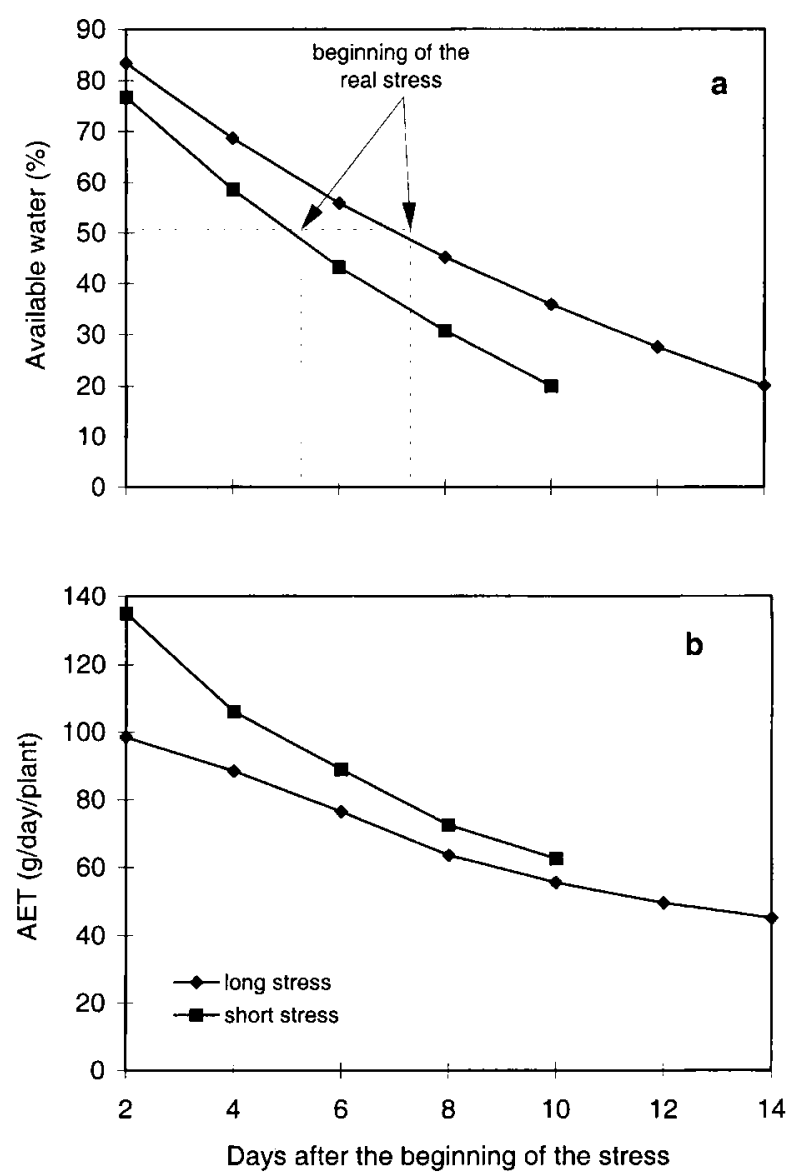

Figure 1. Drying up of the container from the field capacity to $80 \%$ of its value. Examples of two drying up rates, i.e. short and intense stress (10 days) and long and moderate stress (14 days). Mean of four batches of six plants. flowering (p2 phase), a plant had only $37 \%$ of opened flowers (p2), $40 \%$ of buds (p1) and $23 \%$ of pods at the beginning of the elongation phase (p4) (figure 2). Depending on the crop, overlapping was highest between days 10 and 22 after the beginning of flowering. This shows how difficult it is to determine the most susceptible phenological phase to water stress.

\subsection{Natural abortion phenomenon}

The natural abortion rate was quite high even under optimum water conditions, and exceded 0.5 (figure $3 a$ ). Statistical analysis showed a highly significant difference in the abortion probability between the different phenological phases. This probability decreased with the development of each flowering organ. It varied from $0.55-0.60$ for a bud (p1) to 0-0.06 for a pod at the end of the filling stage (p7).

The fall of flowering organs from tagging date to harvest was relatively high and constant for the the floral period (p1-p3) with 1.30 to $1.45 \%$ of organs per day. The value was lower during the pod elongation period (p4 and p5) with 0.5 to $1 \%$ of organs per day. During the filling period (p6 and

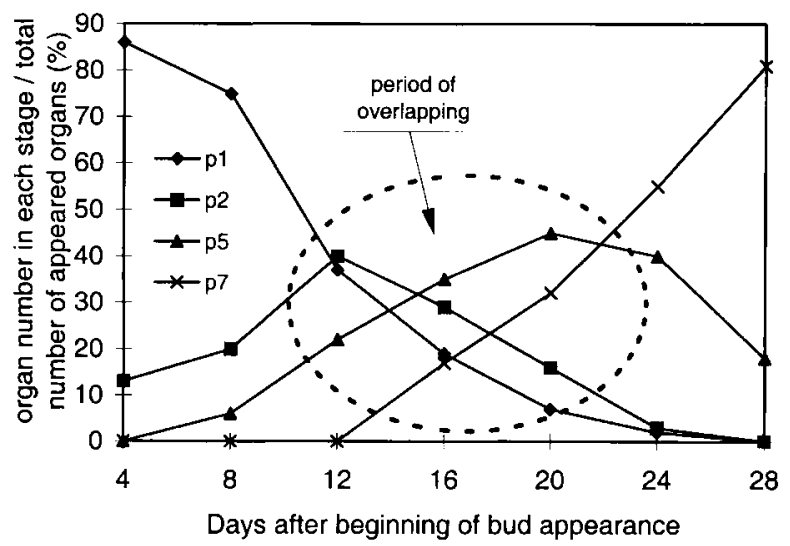

Figure 2. Variation in the number of flowering organs at different phenological phases in the same plant during the reproductive period. Organs were counted every 4 days after the beginning of the flowering period. The measurements were made on four batches of six plants (mean of three experiments). 
p7), the fall was almost insignificant $(0.14 \%$ of organs per day) (figure $3 b$ ). The results over the 3 years were not significantly different and there was no interaction (phases $\times$ years).

The very low abortion rate after the p5 stage confirms that the abortion limit of pods corresponds to the end of the elongation period as shown by Ney et al. [18]. Determining the abortion limit phase can be useful for predicting yield, which can be calculated from this phase.
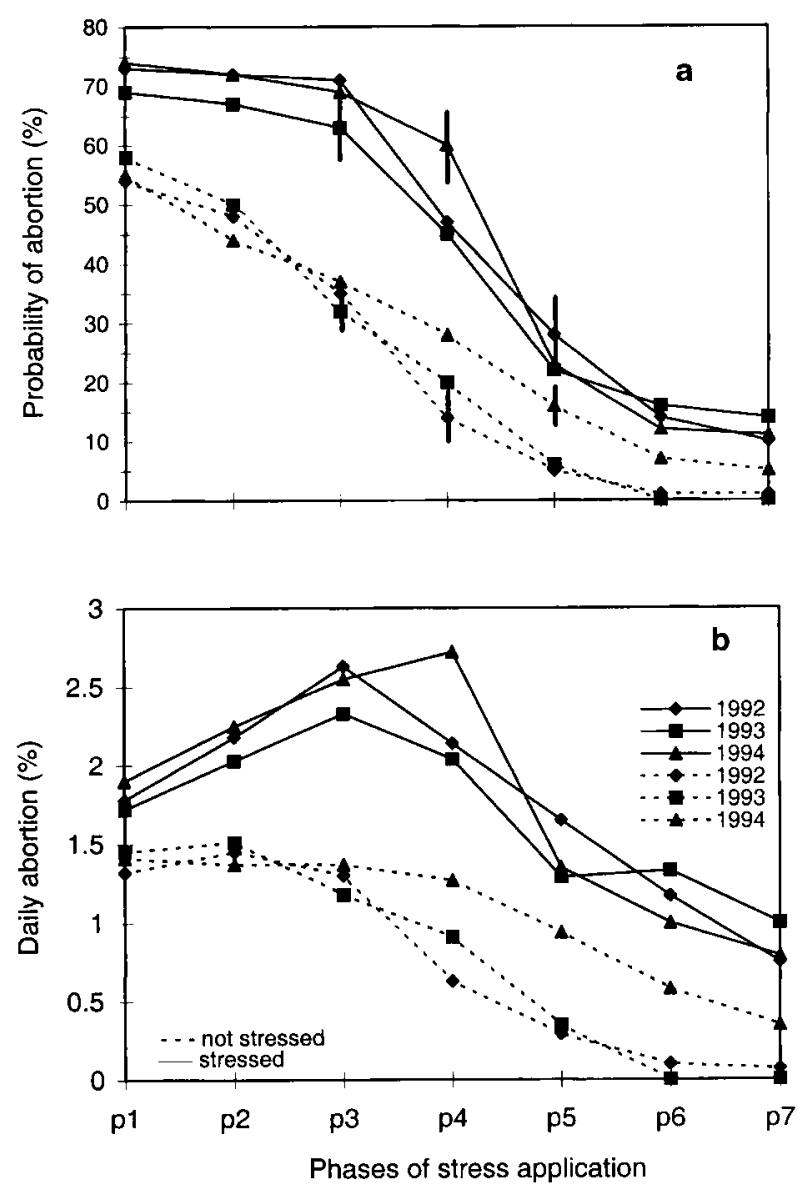

Figure 3. Influence of the stress application period on (a) the abortion probability of a tagged flowering organ at the end of the stress period. This probability is represented by the combination of the organs belonging to the same phenological phase which fell between the tagging date and physiological maturity. (b) The daily abortion rate between the tagging date and the physiological ripeness. (Mean of four batches of six plants.) Least significant difference at the 0.05 threshold.

\subsection{Abortion due to water stress}

Water stress caused an increase in the fall of flowering organs (figure $3 a$ ) since the abortion probability of a stressed bud was $0.69-0.74$, depending on the year, compared with 0.50 for control buds. The difference between years is small, although stress intensity and duration were not exactly the same.

The statistical analysis showed a highly significant difference between the two water regimes and a very highly significant difference between the seven phenological phases.

The increase in the abortion probability due to stress was maximum when stress was applied during fruiting set (p3), during which it varied from 26 to $35 \%$ (depending on the year) and the nearest stages ( $\mathrm{p} 4$ and $\mathrm{p} 2$ ). It was only 5 to $14 \%$ for a stress applied at the $\mathrm{p} 7$ phase (figure 4).

In a stressed plant, the daily mean abortion percentage was also maximum when stress was applied during fruiting set (p3) with a mean of $2.5 \%$ of organs per day. It was minimum when stress was applied during the filling phase $(0.8 \%$ of organs per day) (figure $3 b$ ).

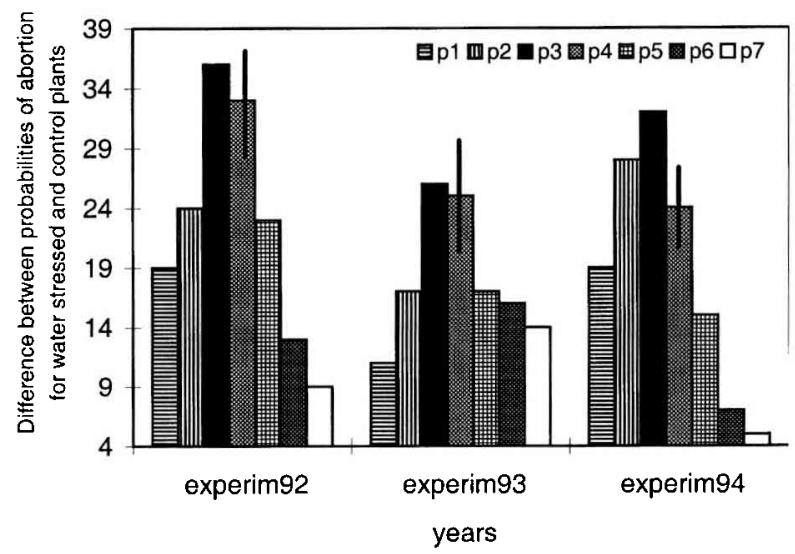

Figure 4. Increase in the abortion probability caused by a stress applied at seven different phenological phases of the reproductive period. The difference is expressed in percent in comparison to the control. Mean of four batches of six plants. 


\subsection{Effect of water stress on the pod number per plant}

The sensitivity of fruiting organs to water stress decreased with their developmental stage: the pod number per plant was lower for water stress applied at the beginning (phases p1, p2 and p3 which have a similar sensitivity) rather than at the end of the reproductive period (figure $5 a$ ). The results from the three experiments show that plants stressed during the bud phase (p1) produced 32 to $47 \%$ fewer pods (depending on the crop) than plants stressed during the grain filling phase $(\mathrm{p} 7)$. Beyond the fruiting set phase, sensitivity decreased
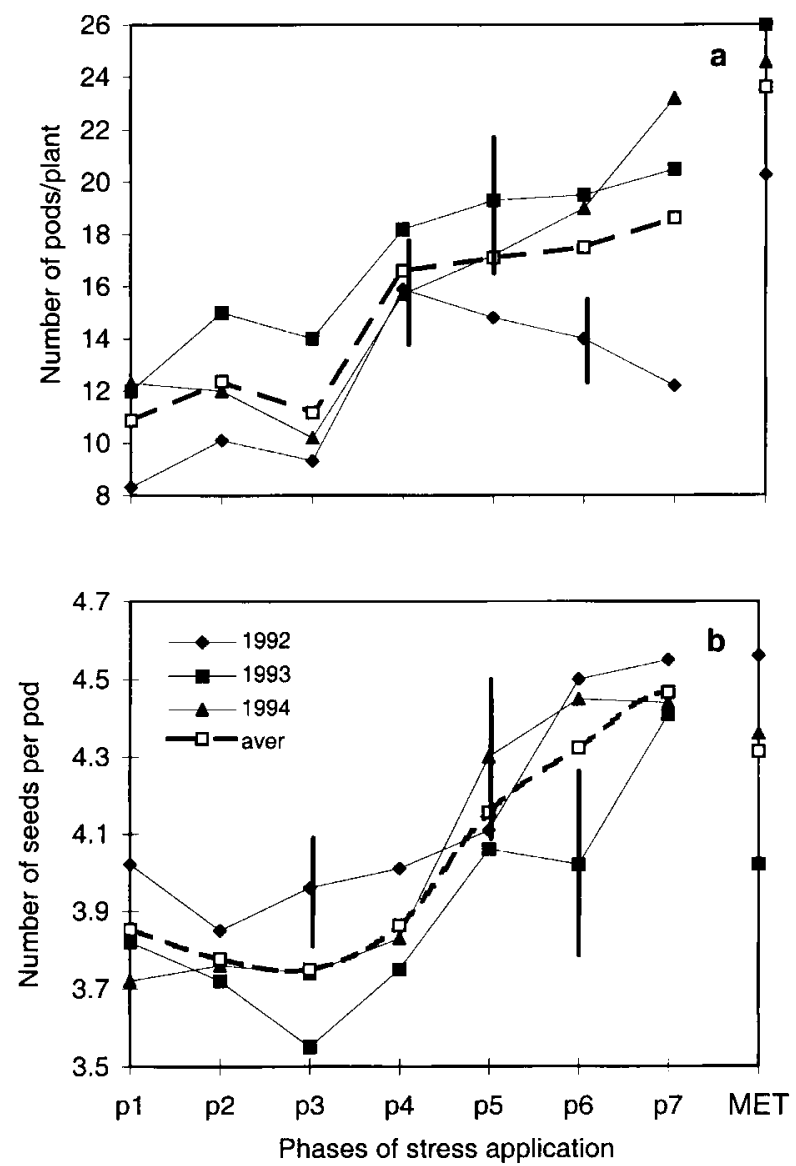

Figure 5. Influence of the stress application period on (a) the pod number per plant (NPo/Pt), (b) the seed number per pod (NS/Po). Mean of four batches of six plants and least significant difference at the 0.05 threshold. roughly linearly up to phase p7. Nevertheless, in 1992, we noted a high sensitivity of the elongation and filling phases (p5-p7). The apparent increase in sensitivity probably resulted from another stress due to very low minimal temperatures (means over 10 days: $11-7^{\circ} \mathrm{C}$ ). Sensitivity of the bean to cold is known and has been illustrated by Bouwkamp and Summers [4] who observed a decrease in pollen germination of 45-65\% for temperatures ranging from 6 to $8^{\circ} \mathrm{C}$.

\subsection{Effect of water stress on the seed number per pod}

The seed number per pod indicated that there were two distinct phases during the reproductive period (figure $5 b$ ). The most sensitive to stress corresponded to the phases $\mathrm{p} 1-\mathrm{p} 3$ during which a decrease in production in comparison to the less sensitive phase $(\mathrm{p} 7)$ reached $16 \%$ at most. The less sensitive corresponded to the pod elongation and filling periods (p4-p7)

The seed number per pod was a less sensitive yield component than the pod number but its sensitivity was less regular: it showed a small peak during fruiting set (p3).

The low sensitivity of the seed number per pod confirmed the observations of Petersen [20]. This lower sensitivity was also illustrated in 1992: the effect of stress on the pod number was not observed on the seed number per pod.

\subsection{Effect of water stress on the relative production}

The difference in sensitivity to water stress between the two components $\mathrm{NPo} / \mathrm{Pt}$ and NS/Po was confirmed by the results in figure $6 a, b$. The relative production of pods $(\mathrm{NPo} / \mathrm{Pt})_{\mathrm{AET}} /(\mathrm{NPo} / \mathrm{Pt})_{\mathrm{MET}}$ varied from 0.35 to 0.95 in the range of uptake deficits (AET/MET) from 0.15 to 0.40 . Over the same range, the relative production of seeds $(\mathrm{NS} / \mathrm{Po})_{\mathrm{AET}} /(\mathrm{NS} / \mathrm{Po})_{\mathrm{MET}}$ did not go below 0.85 . 

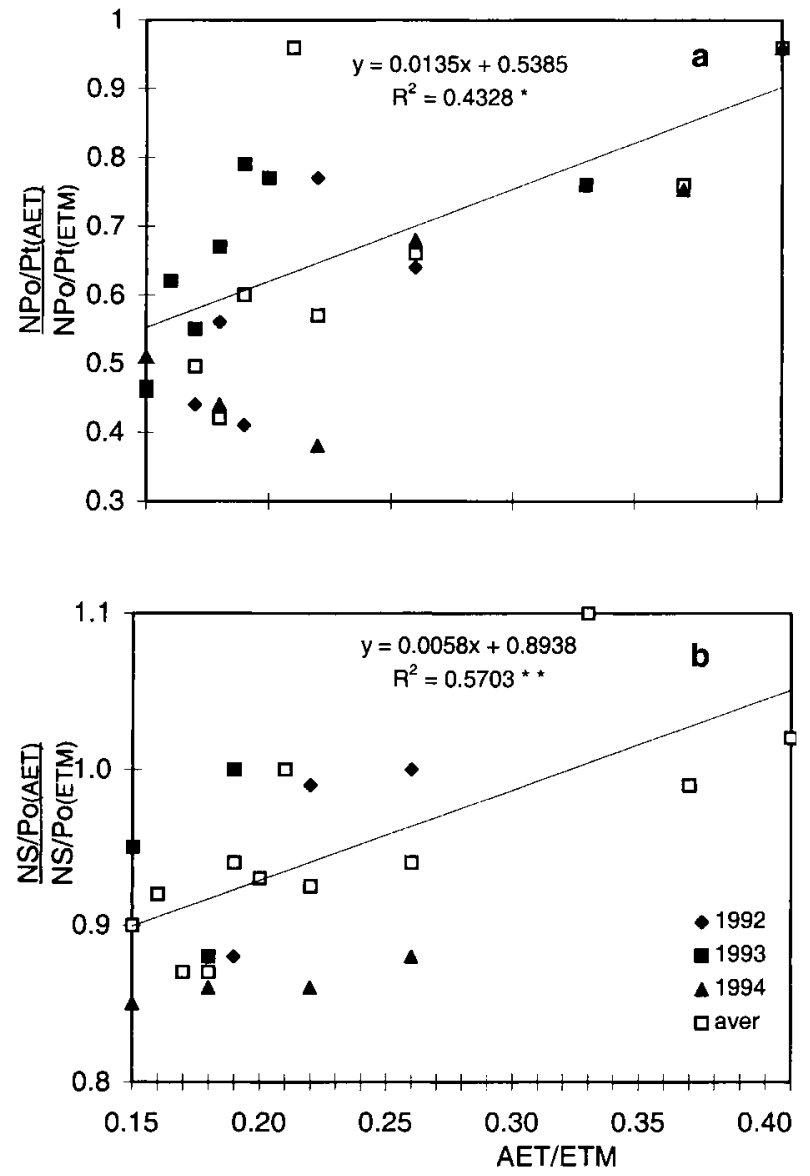

Figure 6. Influence of the stress intensity (AET/AETM) on (a) the relative pod number per plant $\left.(\mathrm{NPo} / \mathrm{Pt})_{\mathrm{AET}} / \mathrm{NPo} / \mathrm{Pt}\right)_{\mathrm{MET}}$, (b) the relative seed number per pod $\left.(\mathrm{NS} / \mathrm{Po})_{\mathrm{AET}} / \mathrm{NS} / \mathrm{Po}\right)_{\mathrm{MET}}$. Mean of four batches of six plants for Npo, NS and AET and ten plants for MET.

This shows a major difference in sensitivity between the pod number and the seed number.

\section{DISCUSSION}

Natural abortion allows the plant to adapt to its environment by decreasing the number of seeds in the case of insufficient carbon resources. The early fall of flowering organs can be caused by various factors. Karamanos and Gimenez [12] observed an antagonism between the activity of the tip of the main stem of the bean and the fruiting set of the pods of the first flowering nodes. Jara [10] obtained a negative correlation between the leaf area index and the seed number per plant. In peas, Jeuffroy and Warembourg [11] ascribe abortion to competition for assimilates between vegetative organs and fruiting organs.

The increase in the abortion rate caused by stress can result from the synthesis of abscisic acid (ABA) $[15,25]$ which provokes leaf abscission and stomatal closure. This mechanism explains the macroscopic observations: stress increases the drying up of leaves [26], pollen seeds and the stigma. This phenomenon is accentuated in the case of high or low [4] temperatures. Water stress can also decrease the flow of assimilates between the different organs of the plant, in particular between leaves and fruiting organs [12]. This hypothesis was confirmed by Schussler and Wesgate [24] who showed that the lack of water reduces carbon supplies to young maize seeds, which leads to their abortion.

The difference in sensitivity between the NPo/Pt and Ns/Po components was mainly due to successive processes determining the pod number and the seed number per pod. Our results showed that the number of organs were highly sensitive to water stress from the opening flowering period (p2) to the beginning of pod elongation (p4). During this period, intensive cell divisions allow fruiting set as shown by Ney et al. [17] in peas.

In peas, Ney et al. [18] have shown that the seed number was greatly affected by water stress while seed weight was little affected because the plant can use its reserves to fill the seeds to varying extents. In peas, Deumier [7] has also shown that the mean weight of the seed can be decreased. Champolivier and Merrien [5] made similar observations in rapeseed. These two adaptation processes, i.e. remobilization of reserves and decrease in the seed weight, have also been observed in other plants, such as maize and wheat.

Comparing the results between years showed that the seed number per pod was higher in 1992 than in 1993. Inversely, the pod number per plant was higher in 1992 than in 1993. Compensation between components is frequent in grain legumes 
[21]. The two components (pod and seed number) can be affected differently. In Vigna radiata subjected to water stress, Kuhad et al. [13] obtained a $33-52 \%$ decrease in the seed number per plant and only $4-9 \%$ in the mean seed weight. These are different effects of stress depending on yield component.

\section{CONCLUSION}

The results obtained during the three experiments show the role played by the overlapping phenomenon of flowering organs at different phenological phases in the same plant during the reproductive period.

Tagging the different flowering organs at the end of the stress period showed a large difference in the sensitivity of pods to abortion depending on which phase stress was applied. Regarding the abortion rate, the pod number per plant and the seed number per pod, the most sensitive phase was the flowering period (fruiting set, p3). The seed filling and maturation phases ( $\mathrm{p} 6$ and $\mathrm{p} 7$ ) were only slightly sensitive to water stress. At an equivalent level of stress, the pod number per plant was much more affected than the seed number per pod.

One of the major conclusions of our study (figure 4 ) is that it is possible to minimize organ abortion by supplying water at flower opening phase (p2), fruit set period (p3) and beginning of pod elongation ( $\mathrm{p} 4)$, because it is the most sensitive period for flowering organs. Because of overlapping phenomena, the plant sensitivity is the combination between percentage of reproductive organs at each stage and sensitivity of organs at this stage. Studying water supply must put together overlapping characterization and stress sensitivity.

Extrapolating the data obtained experimentally to field conditions should be done carefully, because the intensities of the effects observed will probably be different. First, stress intensities vary during the cycle and they are probably stronger at the end, when cropped at the end of the rainfall season. Moreover, since water stress often leads to heterogeneous flower setting in a crop [2, 22], flowering will be less homogeneous and effects will be less pronounced under natural conditions. Last, but not least, the root systems of a crop grown in the field usually have access to much larger volumes of soil and consequently to larger volumes of water. Therefore, stresses would develop more slowly and take much longer to become severe than the short times that occurred in the pots. Thus, there would be more opportunity for plants to adapt as stress developed.

Nevertheless, the method we suggest will be of great interest for studying water stress effect on all indeterminate plants cultivated for their fruit, because the main conclusion is the necessity to study separately overlapping phenomena and stage sensitivity.

\section{REFERENCES}

[1] Acosta Gallegos J.A., Kohashi Shibata J., Effects of water stress on growth and yield of indeterminate dry-bean (Phaseolus vulgaris) cultivars, Field Crops Res. 20 (1989) 81-93.

[2] Balatier J. de, Quels sont les effets de la sécheresse sur les flageolets? Unilec France 56 (1987) 26-27.

[3] Bouniols A., Puech J., Mondies M., Influence d'un déficit hydrique appliqué durant la fructification sur la production de soja, Bulletin du G F H N 11 (1982) $39-55$.

[4] Bouwkamp J.C., Summers W.L., Inheritance of resistance to temperature drought stress in the snap bean, J. Hered. 73, (1982) 385-386.

[5] Champolivier L., Merrien A., Effects of Water stress applied at different growth stages to Brassica napus $\mathrm{L}$ var. Oleifera on yield components and seed quality, Eur. J. Agronomy 5 (1996) 153-160.

[6] De Magalhaes A.A., Millar A.A., Choudhury E.N., Efeito do déficit de agua no periodo reprodutivo sobre aproducçao do feijao, Pesq. Agropec. Bras. 13 (1978) 55-60.

[7] Deumier J.M., L'irrigation des pois protéagineux, Bulletin Fnams Semences 111 (1990) 26-29.

[8] Fiegenbaum V., Dos Santos D.S.B., Mello V.D.C., Gomes Dos Santos Filho B., Tillmann M.A.A., Da Silva J.B., Influencia do deficit hidrico sobre os 
componentes de rendimento de tres cultivares de feijao, Pesq. Agropec. Bras. 26 (1991) 1885-1892.

[9] Floor Drees E.M., The influence of drought stress on flowering and abscission of Phaseolus vulgaris L., Annual report of the bean improvement cooperative 27 (1984) 191-192.

[10] Jara J.R., Repuesta a sequia de cinco variedades de frejol (Phaseolus vulgaris L). Estudio Preliminar, Agro-Ciencia 6 (1990) 95-101.

[11] Jeuffroy M.H., Warembourg F.R., Carbon transfer and partitioning between vegetative and reproductive organs in Pisum sativum L., Plant Physiol. 97 (1991) $440-448$.

[12] Karamanos A.J., Gimenez C., Physiological factors limiting growth and yield of faba beans, in: Present status and future prospects of faba bean productionand improvement in the mediterranean countries, Proceedings of the Zaragoza/Spain seminar, 27-29 June 1989, Options Méditerranéennes (1991) 79-80.

[13] Kuhad M.S., Sheoran I.S., Kundu B.S., Naudwal A.S., Relative performance of pentafoliate and trifoliate mung bean (Vigna radiata Wilczeck), under water stress, Indian J. Plant Physiol., Vol XXXIII, 2 (1990) 168-171.

[14] Laurent E., Les haricots ne supportent pas le stress, Bulletin Semences 119 (1992) 38-40.

[15] Mazliak P., Physiologie végétale II. Croissance et développement, Hermann, Paris, 1982.

[16] Mouhouche B., Influence du stress hydrique sur les composantes du rendement du haricot nain, $17 \mathrm{e}$ Conf. Rég. Europ. CIID, Varna (Bulgaria), 16-22 May 1994, 11-17

[17] Ney B., Duthion C., Fontaine E., Timing of reproductives abortion in relation to cell, water content and growth of pea seeds, Crop Sci. 33 (1993) 267-270

[18] Ney B., Duthion C., Turc O., Phenological response of pea to water stress during reproductive development, Crop Sci. 34 (1994) 141-146.

[19] Pena-Cabriales J.J., Castellanos J.Z., Effects of water stress on $\mathrm{N}_{2}$ fixation and grain yield of Phaseolus vulgaris L., Plant and soil 152 (1993) 151-155.

[20] Petersen A.C., Effects of water stress on (Phaseolus vulgaris L) and (Phaseolus latifolius), Freeman. Ph.D. thesis, University of Minnesota (1985) $213 \mathrm{p}$.
[21] Petersen A.C. Jr, Davis D.D., Yield response of (Phaseolus vulgaris $\mathrm{L}$ ) and Phaseolus acutifolius subjected to water stress, Annual report of the bean improvement cooperative 25 (1982) 53-54.

[22] Romic D., Tomic F., Borosic J., Dolanjski D., Romic M., Jankovic M., Marusic J., Geres D., Effects of irrigation on components of secondary crops yields in Croatia. $17^{e}$ Conf. Reg. Europ. Irrig. Drain CIID, Varna (Bulgaria), 16-22 mai 1994 (1994) 19-28.

[23] Sangakkara U.R., Growth yield and nodule activity of Phaseolus vulgaris $\mathrm{L}$ as affected by soil moisture, J. Agron. Crop Sci. 172 (1994) 62-68.

[24] Schussler J.R., Westgate M.E., Assimilate flux determines kernel set at low water potential in maize, Crop Sci. 35 (1995) 1074-1080.

[25] Schwartz A., Wei-Hua Wu, Tucker E.B., Assmann S.M., inhibition of inward $\mathrm{K}^{+}$channel and stomatal response by abscisic acid: an intercellular locus of phytohormone action, Proc. Natl. Acad. Sci. USA 91 (1994) 4019-4023.

[26] Tabbada R.A., Flores M.A.A., Influence of water stress on vegetative and reproductive growth of Phaseolus vulgaris cv White Baguio, Kalikasan, Philipp, J. Biol. 11 (1982) 266-272.

[27] Vartanian N., Particularités adptatives de la moutarde blanche (Sinapis alba L.) à la sécheresse, in: Réponse des plantes aux facteurs climatiques, Actes Coll. Uppsala, 1970, Unesco (1973) 277-288.

[28] Vidal A., Arnaudo D., Arnoux M., La résistance à la sécheresse du soja I. Influence d'un déficit hydrique sur la croissance et la production, Agronomie 1 (1981) 295-302.

[29] Vidal A., Arnaudo D., Arnoux M., La résistance à la sécheresse du soja II. Étude des réactions variétales à un déficit hydrique. Agronomie 1 (1981) 303-314.

[30] Vieira da Silva J.B., Influence de la sécheresse sur la photosynthèse et la croissance du cotonnier, in: Réponse des plantes aux facteurs climatiques, Actes Coll. Uppsala, 1970, Unesco (1973) 213-220.

[31] Wery J., Turc O., Les besoins en eau des productions de semences de légumineuses, Bulletin Semences FNAMS 111 (1990) 22-25.

[32] White J.W., Castillo J.A., Ehleringer J., Associations between productivity, root growth and carbon isotope discrimination in Phaseolus vulgaris under water deficit, Aust. J. Plant Physiol. 17 (1990) 189-198. 